\title{
Systematic Review of the Job Demands and Resources of Academic Staff within Higher Education Institutions
}

\author{
Mineshree Naidoo-Chetty ${ }^{1} \&$ Marieta du Plessis ${ }^{1}$ \\ ${ }^{1}$ Department of Industrial Psychology,University of the Western Cape, Cape Town, South Africa \\ Correspondence: Mineshree Naidoo-Chetty, EMS Faculty, University of the Western Cape, Cape Town, South Africa, \\ South Africa.
}

Received: October 21, 2020

Accepted: February 9, 2021

Online Published: February 20, 2021

doi:10.5430/ijhe.v10n3p268

URL: https://doi.org/10.5430/ijhe.v10n3p268

\begin{abstract}
The Higher Education sector has been through an array of changes, such as globalisation, massification, lack of job security, decolonisation and a number of technological advancements. These changes have impacted academic workload and have increased work pressure with resultant effects on family and work life balance. A review of the existing literature indicates a lack of clarity when it comes to the job demands and job resources inherent to the academic occupation. In order to determine the job demands and job resources of academics, a systematic review of empirical literature is warranted. This paper systematically reviewed empirical research published from 2014 to 2019 investigating job demands and resources based on the job demands-resources model in the higher education environment. Six articles were identified that met the criteria for inclusion. Thus, a list of quantitative, qualitative and organisational job demands as well as organisational and personal resources specific to the academic environment were identified. This will allow Higher Education Institutions to provide targeted development of job resources and mitigation of job demands for their academic employees and enable the development of specific interventions.
\end{abstract}

Keywords: job demands, job resources, higher education, academics, systematic review

\section{Introduction}

Higher education institutions are facing major transformation challenges globally. Student registrations have risen considerably over the past few years and it would appear that academics are furthermore expected to take on more administrative and management duties (CHE, 2010; Ntshoe \& De Villiers, 2008). Current statistics reveal that the job demands of academics have escalated (due to the forces of internationalisation and open-learning technology, for example) whilst the levels of support and other resources have declined (Council of Higher Education, 2016; Barkhuizen, 2005). Therefore, higher education institutions no longer provide the low-stress environment they once did (Gillespie, Walsh, Winefield, Dua \& Stough, 2001). Academic employees within higher education institutions are experiencing an overload of job demands, however, they have a shortage of response capabilities, especially when it comes to finances (Viljoen \& Rothmann, 2002). Further demands experienced comprise of hefty workloads, time and resource restrictions, extended working hours, poor pay, poor communication, role uncertainty, lack of acknowledgement, striving for publication, ensuring that support for students are provided and staying abreast of technological developments (Dhanpat, de Braine \& Geldenhuys, 2019; Mushemeza, 2016; Ngoc, Hoang \& Hung, 2020). University teaching is known to be stressful (Han, Yin, Wang \& Bai, 2019), and that the job demands of faculty members, in terms of stressors, are closely associated to negative outcomes, including dissatisfaction and greater likelihood of burnout (Renshaw, Long \& Cook, 2015). Regardless of reporting high levels of stress and increased demands, there is some evidence that academics also achieve a substantial amount of satisfaction from their work (Rothmann \& Essenko, 2007).

Job resources are those elements that assist when job demands become too much (Demerouti, Bakker, Nachreiner \& Schaufeli, 2001). The Job Demands-Resources (JD-R) model puts forward that resources play an integral part in the prevention health-impairment process, but can equally act as an antecedent to motivation related outcomes such as enhanced commitment and dedication (Mostert, 2011). The JD-R theoretical framework places employee well-being at the focal point as well as considering employee behaviour and organisational outcomes such as absenteeism, productivity, organisational citizenship and client gratification (Bakker \& Demerouti, 2018). Employees are consequently respected in their own right as they can safeguard other resources, thus preventing a future loss of resources and the improvement of the process of future resource gain (Hakanen, Peeters \& Perhoniemi, 2011). By 
associating job demands with adequate job resources, individuals can challenge themselves to engage in tangible and more demanding professional undertakings, thereby enhancing the pleasure of performing tasks. Similarly, if there are greater demands and scarce resources, there would be a greater chance of illness and strain amongst employees (Schaufeli, Salanova, González-Romá \& Bakker, 2002).

The JD-R model captures the dynamic interaction between job demands and job resources. Specifically, it maintains that when employees have an adequate level of job resources that assist them in successfully coping with their job demands, it spurs an extrinsic and intrinsic motivational process that leads to higher levels of engagement (Byrne \& MacDonagh, 2017). This is in line with the Conservation of Resources theory (COR; Hobfoll, 2002) that states that individuals actively strive to obtain, preserve, and protect their resources, including objects, personal characteristics, conditions, and energies (Chen, Westman \& Eden, 2009). The COR theory suggests that resource depletion is psychologically harmful and can result in reduced levels of well-being while the availability of resources contributes to mental health (Janse Van Rensburg, Rothmann \& Diedericks, 2018). Accordingly, psychological stress occurs when individuals' resources are depleted or threatened, or when they fail to gain resources after resource investment. Persons who lose resources experience actual stress, or when resources are threatened, they will experience anticipatory stress before any actual resource loss occurs (Chen et al., 2009).

Job demands can be classified based on the volume (quantitative demands) and complexity/difficulty (qualitative demands). Quantitative demands are related to the number of tasks and the speed at which it can be accomplished. Thus when quantitative work demands are elevated, work tasks will necessitate more time than what was planned for (van Veldhoven, 2014). Qualitative demands focuses on the type of skills and/or effort required to complete work tasks. For example, cognitive, emotional or physical skills and/or effort. It refers to the level of difficulty or complexity that is needed to carry out the job (Bowling \& Kirkendall, 2012). In addition, demands can also be classified as organisational demands. These types of demands impact individual performance negatively in terms of work outputs (Bakker, Demerouti \& Verbeke, 2004). Similarly, job resources can be classified as organisational and personal resource, depending on the source of the resource (Schaufeli \& Taris, 2014).

One of the main assumptions of the JD-R model is that every occupation has its own specific risk factors associated with job-related stress (Demerouti \& Bakker, 2011). It is therefore important to understand what demands and resources exist in the academic environment. Due to the fragmented nature literature of job demands and job resources inherent to the academic occupation, the current study aimed to synthesise literature through a systematic review to provide a clearer picture of the contemporary demands and resources of the academic. The review further included an exploration of the empirically established influence of job demands and resources on individual and organisational outcomes. The objectives of the study were therefore to:

1) To determine what job demands, job resources and associated outcomes relevant to the academic role have been studied; and

2) To review the empirically tested relationships between academic job demands and resources and consequences.

\section{Methodology}

\subsection{Research Design}

A systematic review was undertaken to identify published literature on job demands and resources within the Higher Education Sector. A systematic review uses a clear algorithm, as opposed to a heuristic, to achieve a search and critical appraisal of the literature (Arksey \& O'Malley, 2005).

\subsection{Eligibility Criteria}

Studies were included if the desired criteria were satisfied, i.e. a focus on job demands and/or job resources of academic staff and utilising the JD-R model as theoretical framework. In addition, studies that included academics as the target audience were sought, and the time frame of $2014-2019$ was considered. This time period was chosen to reflect recency of job demands and resources within the Higher Education context. The British Council report on Higher Education (2012) estimated a 1.4\% growth in global Higher Education enrolments between the period of 2011 and 2020; thus numerous changes between 2014 - 2019 are estimated ("Higher education global trends and emerging opportunities to 2020", 2012). Within the South African context the period from 2014 was characterised by student protest actions that resulted in mental and emotional demands for academics (Du Plessis, 2020).

The systematic review excluded all studies that was not in English. Studies that were not included in the subscribed or open access databases of the researchers' library access were not considered for the systematic review. This could 
potentially reduce the body of knowledge that is being used for the study and thus could impact the study and the findings.

\subsection{Search Strategy}

The following databases, Science direct, Scopus, Sage, Sabinet, Ebscohost, Emerald Insight and Wiley online was chosen due to their relevance to the topic. These databases were systematically searched by two reviewers in November 2019. A preliminary search of these databases revealed that these databases contained appropriate and current evidence pertaining to the review. The following keywords were used in the current study: 'Job demands, Job resources, higher education, university, college, academic staff'. Strings of keywords were created using The Boolean operator 'AND' and was entered in to 'All fields' in the respective database. The Boolean strings of keywords and search terms are presented below:

The Boolean strings of keywords and search terms are as follows:

(1) job demands AND higher education

(2) job demands AND higher education AND academics

(3) job demands AND university

(4) job resources AND higher education

(5) job resources AND higher education AND academics

(6) job demands AND (higher education* OR college* OR university* OR higher education institutions*)

(7) job demands AND university teachers

(8) job resources AND university teachers

(9) job demands AND higher education professionals

(10) job demands AND higher education professionals

Limiters were applied consistently to all searches. These limiters included peer-review, full-text, English medium, published between $2014-2019$.

\subsection{Study Selection}

The target population considered for this study was required to include academic staff currently employed at a higher education institution. Both international and national studies of qualitative, quantitative and mixed methodology designs were considered for inclusion in the review. Studies were further required to report on the target population, setting, and the identified job demands and or the job resources that the academic staff were experiencing. As this study embodies a systematic review methodology, other systematic reviews were excluded from the study. Additionally, studies not focused on academics as the target population, and that is not set within a higher education setting or does not include primary data was not considered for review.

\section{Identification}

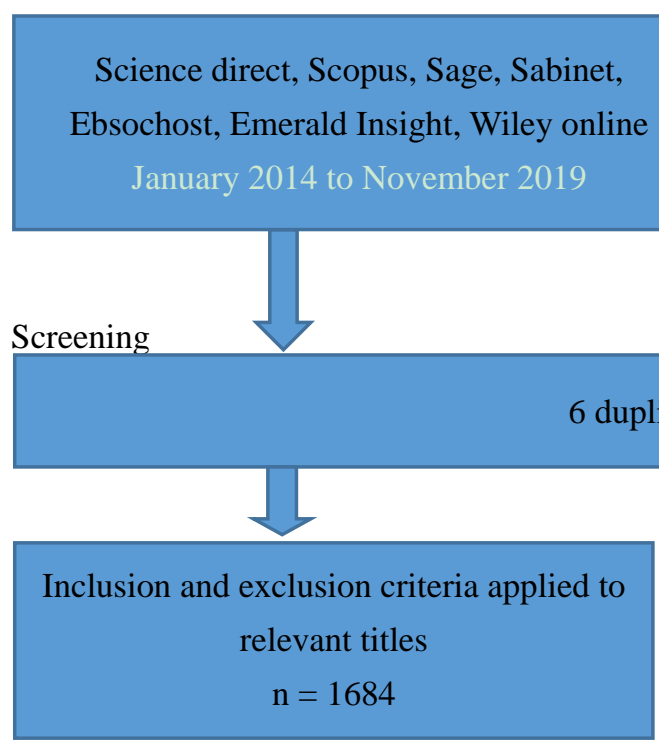

Published by Sciedu Press

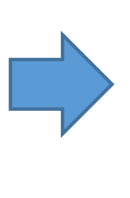

270

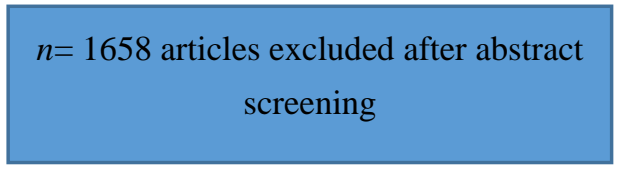

ISSN 1927-6044 E-ISSN 1927-6052 
Eligibility

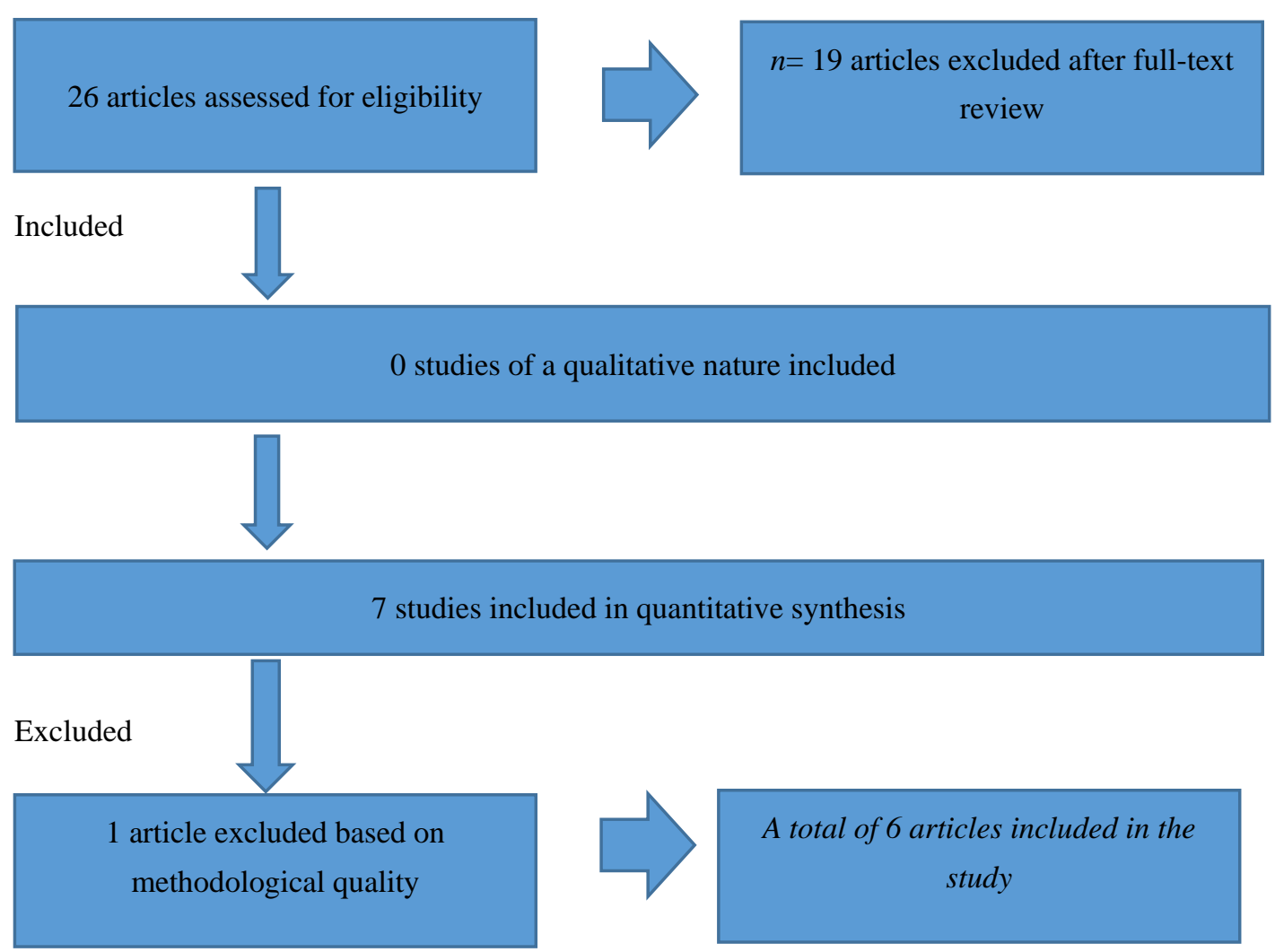

Figure 1. Methodological Quality Assessment

The full-text of potential studies were assessed for methodological quality using the PRISMA critical appraisal tool. The PRISMA critical appraisal tool consists of four dimensions (1) Identification; (2) Screening; (3) Eligibility; and (4) Included (Moher, Liberati, Tetzlaff, Altman, 2009). The PRISMA appraisal tool was rated using dichotomous scale of yes (1) or no (0) resulting in a composite score indicating the methodological quality and reporting on the intervention. Articles that scored less than $70 \%$ were omitted demonstrating that they were poorly developed or executed. All three levels of review were conducted by two researchers working independently. If there were any discrepancies regarding the inclusion criteria, they were discussed by reviewers. If no compromise was reached, a third independent reviewer was consulted.

\section{Data Extraction}

A data extraction sheet developed by Isaacs, Roman, Savahl and Sui (2018) was adapted for the extraction of data from included studies. The data extraction sheet consists of six categories namely, (1) authors and year; (2) method target population; (3) job demands; (4) job resources; (5) consequences (Lack of Job resources and too many demands); and (6) aim of the study. The results of the data extraction is reported in Table 1. 
Table 1. Data extraction

\begin{tabular}{|c|c|c|c|c|c|}
\hline $\begin{array}{l}\text { Authors } \\
\& \\
\text { Year }\end{array}$ & $\begin{array}{l}\text { Target population } \\
\text { And method }\end{array}$ & Job demands & Job resources & Consequences & Aim of the study \\
\hline $\begin{array}{l}\text { 1. Alzyoud } \\
\text { (2016) }\end{array}$ & $\begin{array}{l}\text { Four Jordanian } \\
\text { institutions }(n=532)\end{array}$ & $\begin{array}{l}\text { Academic } \\
\text { workload } \\
\text { Work pressure }\end{array}$ & $\begin{array}{l}\text { Autonomy } \\
\text { Social support } \\
\text { Performance } \\
\text { feedback }\end{array}$ & $\begin{array}{l}\text { Of job resources: } \\
\uparrow \text { Work engagement } \\
\uparrow \text { Job satisfaction } \\
\text { Of job demands: } \\
\downarrow \text { Work engagement } \\
\downarrow J \text { Job satisfaction } \\
\text { Job satisfaction } \\
\text { mediates the } \\
\text { relationship job } \\
\text { between job } \\
\text { demands and jork } \\
\text { resources, and work } \\
\text { engagement }\end{array}$ & $\begin{array}{l}\text { To determine the extent to } \\
\text { which job satisfaction } \\
\text { mediated the relationship } \\
\text { between job } \\
\text { demands-resources and } \\
\text { work engagement of } \\
\text { academic staff. }\end{array}$ \\
\hline $\begin{array}{l}2 . \quad \text { Mudrak, } \\
\text { Zabrodska, } \\
\text { Kveton, Jelinek, } \\
\text { Blatny, Solcova, } \\
\text { \&Machovcova } \\
(2018)\end{array}$ & $\begin{array}{l}\text { The study participants } \\
\text { were }(\mathrm{n}=1389) \text { full-time } \\
\text { faculty members } \\
\text { employed } \\
\text { in public universities in } \\
\text { the Czech Republic. } \\
\text { Ouantitative method }\end{array}$ & $\begin{array}{l}\text { Job insecurity } \\
\text { Work-family } \\
\text { conflict } \\
\text { Quantitative } \\
\text { demands } \\
\text { (extended hours of } \\
\text { working) }\end{array}$ & $\begin{array}{l}\text { Support from } \\
\text { supervisors } \\
\text { Support from } \\
\text { colleagues } \\
\text { Influence over } \\
\text { their work } \\
\text { (Autonomy) }\end{array}$ & $\begin{array}{l}\text { Of job resources: } \\
\uparrow \text { Work engagement } \\
\uparrow \text { Job satisfaction } \\
\text { Of job demands: } \\
\uparrow \text { Stress }\end{array}$ & $\begin{array}{l}\text { To determine how } \\
\text { academics at Czech } \\
\text { public universities } \\
\text { perceived their } \\
\text { workplaces and how these } \\
\text { perceptions related to } \\
\text { their occupational } \\
\text { well-being }\end{array}$ \\
\hline $\begin{array}{l}\text { 3. Nurendra } \\
\text { (2018) }\end{array}$ & $\begin{array}{l}\text { The study participants } \\
\text { were ( } \mathrm{n}=83) \text { lecturers } \\
\text { from a university in } \\
\text { Yogyakarta. } \\
\text { Quantitative method }\end{array}$ & $\begin{array}{l}\text { Workload } \\
\text { Emotional } \\
\text { demands } \\
\text { Work-home } \\
\text { interference }\end{array}$ & $\begin{array}{l}\text { Autonomy } \\
\text { Self-developm } \\
\text { ent } \\
\text { opportunities } \\
\text { Social support }\end{array}$ & $\begin{array}{l}\text { Of job resources: } \\
\uparrow \text { Work engagement } \\
\text { Of job demands: } \\
\downarrow \text { Work engagement } \\
\text { Job resources have a } \\
\text { significant } \\
\text { moderating role } \\
\text { between job } \\
\text { demands and work } \\
\text { engagement }\end{array}$ & $\begin{array}{l}\text { To examine the role of job } \\
\text { resources as the } \\
\text { moderating variable in the } \\
\text { relationship between job } \\
\text { demands and work } \\
\text { engagement on lecturers. }\end{array}$ \\
\hline
\end{tabular}




\begin{tabular}{|c|c|c|}
\hline \multirow{6}{*}{$\begin{array}{l}\text { 4. Dhanphat, de } \\
\text { Braine \& } \\
\text { Geldenhuys } \\
\text { (2019) }\end{array}$} & Participants were $(n=184)$ & Work overload \\
\hline & $\begin{array}{l}\text { lecturers from } \\
\text { across universities in }\end{array}$ & $\begin{array}{l}\text { Higher education } \\
\text { unrest }\end{array}$ \\
\hline & South Africa & $\begin{array}{l}\text { Change } \\
\text { management }\end{array}$ \\
\hline & Quantitative method & Decolonisation \\
\hline & & $\begin{array}{l}\text { Online teaching } \\
\text { and learning }\end{array}$ \\
\hline & & $\begin{array}{ll}\text { Lack } & \text { of } \\
\text { psychological } & \\
\text { safety } & \end{array}$ \\
\hline
\end{tabular}

5. Han, Yin, Wang \& Bai (2019)

\begin{abstract}
University lecturers $(n=2758)$ from East China participated in this study. Lecturers were from key national universities, provincial vocational institutions
\end{abstract}

$\begin{array}{ll}\text { Teaching load } & \text { Teaching } \\ \text { New technology } & \text { resources } \\ \text { and innovation } & \text { Peer support } \\ \text { Research } & \text { Administrativ } \\ \text { demands } & \text { e support } \\ & \begin{array}{l}\text { Teacher } \\ \text { efficacy }\end{array}\end{array}$

Quantitative method
N/A

N/A

To construct and theoretically validate the Higher Education Hindrance Demands Scale through exploratory factor analysis
Of job resources:

$\uparrow$ Work engagement

$\downarrow$ Emotional

exhaustion

Of job demands:

$\uparrow$ Emotional

exhaustion

$\downarrow$ Work engagement

Teacher efficacy (as personal resource) mediated the relationship between job resources and work engagement

6. Converso, Professors $(\mathrm{n}=291)$ within Sottimano, a public higher education Molinengo \& institution in Italy Loera (2019)

Quantitative method

\begin{tabular}{|c|c|c|}
\hline Work overl & & Meaningfulne \\
\hline Conflict & with & ss of work \\
\hline colleagues & & Reward \\
\hline
\end{tabular}

Of job resources: $\downarrow$ Psychological

diseases

$\downarrow$ Intention to leave

$\downarrow$ Emotional exhaustion

$\downarrow$ Workaholism

$\downarrow$ Work-family life conflict

$\uparrow$ Work engagement

$\uparrow$ Job satisfaction

\section{Of job demands:}

$\uparrow$ Psychological

diseases
This study investigated the associations between challenge job demands,

job resources, emotional exhaustion and work engagement, and examined

the mediation effect of teacher efficacy as a personal resource in the job

demands-resources model

To examine the associations of certain job resources

(meaningfulness of work, reward) and job demands (work overload, conflict among colleagues) with workaholism, emotional exhaustion and engagement. 
Note:

$\uparrow$ - Refers to a positive increase in the listed variable.

$\downarrow$ - Refers to a decrease in the listed variable.

3.1 Data Analysis

A narrative synthesis was deemed suitable for the review as it included quantitative, qualitative and mixed method study designs. As outcomes of the included studies are heterogeneous in nature, a meta-analysis would not have been feasible. Apparent themes emerging from the data shall be presented in the findings section below.

\subsection{Ethical Considerations}

The study made use of published sources that are either freely available, or available on subscription to researchers. In addition, ethical approval was obtained from the researcher's institution.

\section{Study Selection/ Search and Retrieval Process}

The systematic search generated 1684 articles. The titles, abstracts, and keywords of these articles were reviewed. Out of this, 1658 studies were excluded because they did not meet the eligibility criteria and only 26 articles indicated their relevance to the topic under study. Some of the studies were excluded because they touched only on Job demands or Job resources but did not consider higher education or academics, or were impacted by other constructs such as age, organisational commitment, meaning of work or workflow. Further, other studies excluded at this stage were based on the fact that they were conceptual studies or reviews and did not contain empirical results. Out of 26 articles, only seven articles were meticulously read as the difference of 6 articles were duplicates from the different databases that were used. In the last stage, seven articles were screened and analysed with the adapted version of the Methodological Quality Appraisal Tool (Roman \& Frantz, 2013). Finally, only one article was excluded based on the Methodological Quality Appraisal Tool and thus six articles were used for the review.

\section{Methodological Quality Appraisal}

The methodological quality was assessed using the methodological quality appraisal tool adapted from Roman and Frantz (2013). The methodological quality appraisal sheet, presented in Table 2, consists of six categories used to appraise the sampling methods namely, (1) sampling method, (2) response rate, (3) validity and reliability of the measuring tool, (4) data source, (5) definitions of the variables and, (6) exploration of these variables in the higher education sector. A possible inclusion within the review is considered when the methodological quality appraisal score is obtained as satisfactory or good. 
Table 2. Methodological quality of included articles

\begin{tabular}{|c|c|c|c|c|c|c|}
\hline Questions & $\begin{array}{l}\text { Alzyoud } \\
\text { (2016) }\end{array}$ & $\begin{array}{l}\text { Mudrak, } \\
\text { Zabrodska, } \\
\text { Kveton, Jelinek, } \\
\text { Blatny, Solcova, } \\
\text { Machovcova } \\
(2018)\end{array}$ & $\begin{array}{l}\text { Nurendra } \\
\text { (2018) }\end{array}$ & $\begin{array}{l}\text { Dhanphat, de } \\
\text { Braine \& } \\
\text { Geldenhuys } \\
(2019)\end{array}$ & $\begin{array}{l}\text { Han, Yin, } \\
\text { Wang \& } \\
\text { Bai } \\
(2019)\end{array}$ & $\begin{array}{l}\text { Converso, } \\
\text { Sottimano, } \\
\text { Molinengo \& } \\
\text { Loera (2019) }\end{array}$ \\
\hline $\begin{array}{l}\text { In the empirical } \\
\text { analysis of the study, is } \\
\text { the JD-R specifically } \\
\text { discussed/ }\end{array}$ & 1 & 1 & 1 & 1 & 1 & 1 \\
\hline Defined & & & & & & \\
\hline $\begin{array}{l}\text { Is job demands and } \\
\text { resources in the HE } \\
\text { sector being explored in } \\
\text { the study? }\end{array}$ & 1 & 1 & 1 & 1 & 1 & 1 \\
\hline $\begin{array}{l}\text { Is the JD-R model used } \\
\text { as a theoretical } \\
\text { framework? }\end{array}$ & 1 & 1 & 1 & 1 & 1 & 1 \\
\hline $\begin{array}{l}\text { Was the sampling } \\
\text { method representative } \\
\text { of the population } \\
\text { intended to study? }\end{array}$ & 1 & 1 & 1 & 1 & 1 & 1 \\
\hline $\begin{array}{l}\text { Did the study report any } \\
\text { response rate? (If the } \\
\text { reported response rate is } \\
\text { less than } 60 \% \text {, the } \\
\text { question should be } \\
\text { answered 'No'.) }\end{array}$ & 0 & 1 & 0 & 0 & 1 & 0 \\
\hline $\begin{array}{l}\text { Was the measurement } \\
\text { tool used valid and } \\
\text { reliable? }\end{array}$ & 1 & 1 & 1 & 1 & 1 & 1 \\
\hline $\begin{array}{l}\text { What was the source of } \\
\text { the data? (Primary }(1) / \\
\text { Secondary }(0)\end{array}$ & 1 & 1 & 1 & 1 & 1 & 1 \\
\hline Calculation & $6 / 7 * 100$ & $7 / 7 * 100$ & $6 / 7 * 100$ & $6 / 7 * 100$ & $7 / 7 * 100$ & $6 / 7 * 100$ \\
\hline Total & $85 \%$ & $100 \%$ & $85 \%$ & $85 \%$ & $100 \%$ & $85 \%$ \\
\hline Comments & Good & Good & Good & Good & Good & Good \\
\hline
\end{tabular}

\section{Findings}

Of the reviewed articles, two of the studies were conducted in South Africa, whilst the remaining studies were conducted in countries such as Jordan, Czech Republic, Indonesia, East China and Italy. The participants consisted of 
academic staff that ranged from the level of Professors to junior lecturers. Data were collected by means of survey questionnaires in all the studies. In terms of tenure, the majority of the studies indicated that academic staff had organisational tenure of at least 3 years.

Out of the six studies that were reviewed, only three of the studies indicated their sampling technique. This included non-probability sampling (Dhanpat et al., 2019), convenience (Mudrak et al., 2018) and also stratified sampling (Han et al., 2019), whilst the other three studies made no mention of their sampling method. All studies that were conducted was done in an academic environment i.e. a higher education institutional setting. Lastly, all the studies considered JD-R framework as part of their study.

The identified job demands and job resources from the six articles are presented in Table 3 and 4. The definitions provided were extracted from the reviewed articles, and supplemented with information from literature. The researchers organised the list based on quantitative, qualitative and organisational demands; and personal and organisational resources.

Table 3. Job demands identified in the systematic review

\begin{tabular}{|c|c|c|}
\hline Demand & Type & Definition \\
\hline Academic workload / Workload & $\begin{array}{l}\text { Quantitative } \\
\text { demand }\end{array}$ & $\begin{array}{l}\text { In occupational health and research, elevated } \\
\text { workload signifies a typical job demand and labels } \\
\text { the situation as having a lot of work to do within a } \\
\text { limited time period. It is associated with aspects } \\
\text { such as time pressure (Kumar, Duggirala, } \\
\text { Hayatnagarkar \& Balaraman, 2017). }\end{array}$ \\
\hline Work pressure & $\begin{array}{l}\text { Quantitative } \\
\text { demand }\end{array}$ & $\begin{array}{l}\text { Work pressure is perceived of as a } \\
\text { cognitive-energetic state of the individual, creating } \\
\text { the feeling of strain or felt pressure, which is } \\
\text { related with the continuing and expected execution } \\
\text { of work tasks (Roe \& Zijlstra, 2000). }\end{array}$ \\
\hline Change management & $\begin{array}{l}\text { Quantitative } \\
\text { demand }\end{array}$ & $\begin{array}{l}\text { This notion is about transformation that affects all } \\
\text { aspects in society thus bringing about doubt and } \\
\text { generating innovative prospects of how to manage } \\
\text { changes (Bowin, 2001). Change in HEI's refers to } \\
\text { changes that has been taking place since } 2001 \\
\text { resulting from institutional restructuring to meet } \\
\text { the necessities of the emerging. }\end{array}$ \\
\hline Research demands & $\begin{array}{l}\text { Quantitative } \\
\text { demand }\end{array}$ & $\begin{array}{l}\text { Is the increased competition for scarce funding } \\
\text { resources by putting pressure on faculty members } \\
\text { to yield more. Thus associating university funds to } \\
\text { the number of publications produced (Dvorackova, } \\
\text { Pabian, Smith, Stockelova', Sima, \& Virtova', } \\
\text { 2014). }\end{array}$ \\
\hline Teaching load & $\begin{array}{l}\text { Quantitative } \\
\text { demand }\end{array}$ & $\begin{array}{l}\text { This considers the ratio of students to lecturers. } \\
\text { Student enrolment has increased intensely whereas } \\
\text { teaching roles have stayed somewhat unchanged } \\
\text { (Prudky, Pabian, \& Sima, 2010). }\end{array}$ \\
\hline $\begin{array}{l}\text { Work-family conflict (extended } \\
\text { hours of working)/ } \\
\text { Work home interference }\end{array}$ & $\begin{array}{l}\text { Qualitative } \\
\text { demand }\end{array}$ & $\begin{array}{l}\text { Often considered the failure to manage work and } \\
\text { home life duties due to extended hours of working } \\
\text { (Mudrak et al., 2018). Accordingly, work-family } \\
\text { conflict is viewed as a form of conflict amongst } \\
\text { roles of work and home, where pressures are } \\
\text { difficult to separate (Torp, Lysfjord \& Midje, } \\
\text { 2018). }\end{array}$ \\
\hline Lack of psychological safety & $\begin{array}{l}\text { Qualitative } \\
\text { demand }\end{array}$ & $\begin{array}{l}\text { Edmondson and Lei (2014) elucidate that } \\
\text { psychological safety denotes to the feeling of } \\
\text { safety whereby individuals are able to work } \\
\text { successfully in a fast changing world under }\end{array}$ \\
\hline
\end{tabular}


Emotional demands

Higher education unrest

Decolonisation

Job insecurity

Conflict with colleagues

Online teaching and learning/ New technology and innovation
Qualitative

demand

Organisational demand

Organisational demand

Organisational demand

Organisational demand

Organisational demand conditions of constant development and learning (Edmondson, Higgins, Singer, \& Weiner, 2016).

Emotional demands is about being able to deal with strong feelings such as distress, anger, anxiety, and frustration in the workplace (Mazzetti, Guglielmi \& Topa, 2011).

This refers to the "fees must fall campaign" where academics' work was damagingly affected due to violent demonstrations, interruption of the academic calendar, damage to buildings etc. (Dhanpat et al., 2019)

This refers to dealing with the colonial legacy (knowledge, violence and thought) (Pillay, 2015) which is still deeply rooted within education in South African HEI's (Heleta, 2016)

Job insecurity in the academic setting refers to the amount of short-term contracts, shortage of funding opportunities or external accountability provided (Kinman, Jones \& Kinman, 2006).

This aspect refers to the degree of conflict within the workplace and amongst employees (Converso et al., 2019).

This aspect considers the altering nature of teaching. The movement of blended learning and online education. This evolved way of teaching/learning has ensued with the use of technology (Bennett \& Lockyer, 2004).

Table 4. Job resources identified in the systematic review

\begin{tabular}{lll}
\hline Resource & Type & Definitions \\
\hline Autonomy/ & Organisational & Autonomy is the social climate shaped by \\
Influence over their work & Resource & $\begin{array}{l}\text { management in the workplace, in which } \\
\text { employees viewpoints are recognised, } \\
\text { opportunities for choice are provided, and }\end{array}$ \\
& $\begin{array}{l}\text { self-initiation is encouraged (Deci, Eghrari, } \\
\text { Patrick, \& Leone, 1994). Thus, each employee has } \\
\text { the freedom in deciding how to accomplish their }\end{array}$ \\
& job tasks, being owners of their own attitudes, and \\
being able to act freely (Shirom, Nirel \& Vinokur, \\
2006).
\end{tabular}

Performance feedback Organisational Resource

Support from Supervisors

Administrative support
Organisational Resource

Organisational Resource
This is an evaluative process that entails receiving enough information to carry out ones work objectives, to ensure that development and learning can take place (Bakker, Demerouti, Taris, Schaufeli \& Schreurs, 2003).

This is the degree to which employees' feel valued by their supervisors in addition to and caring about their well-being. It is thus the notion that the supervisor is worried about their welfare, trusts in their capabilities and shows respect to them (Saks, 2006).

This form of support represents support from the administrators, which can assist employees in managing their job demands (Chang, McKeachie 
Teaching Resources

Reward

Support from colleagues

Self-development opportunities

Social support / Peer support

Teacher efficacy

Meaningfulness of work
Organisational Resource

Organisational Resource

Organisational Resource

Organisational Resource

Organisational

Resource

Personal

Resource

Personal

Resource
\& Lin, 2010).

This refers to the facilities and resources provided by the university in order to ensure successful teaching outcomes (Chang et al., 2010).

Reward refers to aspects that include extrinsic rewards such as remuneration and advancement, whereas intrinsic rewards include aspects such as respect and recognition (Moloney, Boxall, Parsons, Cheung, 2017).

This concept is considered a straight forward resource as it is there to assist academics accomplish their work objectives (Bakker \& Demerouti, 2007).

Self-development opportunities refer to the possibilities that the workplace provides to employees to attain knowledge, or to advance and to improve their skills (Bakker et al., 2003).

This concept refers to the perceived support that individuals obtain from their social support network to help control intensified emotions to help cope with environmental demands (du Plessis \& Martins, 2019).

According to Hoy (2004), this notion talks to teachers' judgment about their competence to impact students' level of engagement and learning.

Meaningfulness refers to one's view of the importance of the goals and activities that is carried out at the organisation in relation to an individual's level of self-actualisation and life (Barrick, Mount \& Li 2013).

\section{1 Job Demands}

Quantitative demands within the context of the academic's role was identified as constant high workload/ teaching load (Converso et al., 2019; Dhanpat et al., 2019; Han et al., 2019; Nurendra, 2018), work pressure (Alzyoud, 2016), research demands and also change management (Han et al., 2019). It should be noted that there were more quantitative versus qualitative demands identified in the taxonomy. This could indicate that academics are dealing with copious amounts of work, which attributed to a higher number of quantitative demands being identified.

Qualitative demands were identified as aspects such as work-family conflict, lack of psychological safety and emotional demands. In terms of work-family conflict, dealing with an overload of work/teaching load has a spill over effect as many academics have to take work home or work additional hours. This has a direct impact on their personal lives (Converso et al., 2019). Moreover, with the constant changes that have taken place within the HE sector it comes as no surprise that many academics and their level of psychological safety have been affected negatively (Dhanphat et al., 2019). These types of demands directly affect the academics emotions (Nurendra, 2018) and their ability to deal with the cognitive, emotional or physical demands of the job, as it requires a generous amount of effort.

Finally, organisational demands was seen as characteristics such as Higher Education unrest, Decolonisation, job insecurity, conflict with colleagues, and the ability to grapple with new technology and innovation. Most of these aspects signify that changes are taking place within HE. However, these types of changes create more stress for academics as they are distinctive to the academic environment (other counterparts from the corporate environment do not have to deal with such different and as many aspects) (Dhanpat et al., 2019).

\subsection{Organisational Resources}

Support from colleagues (Han et al., 2019; Mudrak et al., 2018) and social support (Alzyoud, 2016; Nurendra, 2018) were found to assist the academic in dealing with excessive demands. This type of support allows the individual to 
feel that there is someone that cares for his or her well-being (Alzyoud, 2016; Mudrak et al., 2018; Nurendra, 2018; Han et al., 2019).

In addition, the amount of autonomy an organisation provides to the academic (Alzyoud, 2016; Nurendra, 2018), support from supervisors (Mudrak et al., 2018), administrative support (Han et al., 2019), performance feedback (Alzyoud, 2016), influence an academic has over their work (Mudrak et al., 2018), and rewards are all aspects that were highlighted in the study as ways to increase commitment, engagement and performance levels.

\subsection{Personal Resources}

Finally, personal resources are focused on aspects such as teacher efficacy as well as self-development opportunities. These resources impact the individual as it brings enjoyment and the opportunity to advance in one's career (Nurendra, 2018; Alzyoud, 2016).

It should be noted that more organisational resources was identified by academics than personal resources. A reason for this could be that personal resources focus on the views and judgement of the academic (Barrick, Mount \& Li 2013; Hoy, 2014) and organisational resources are retrieved from external sources such as a supervisors or co-workers. Thus, the individual does not need to draw from their own energy for assistance but relies on energy from the organisation (Schaufeli, 2017). However, both these categories are imperative for academics to function optimally.

\subsection{Relationship between Job Demands, Job Resources and Outcomes}

The relationships portrayed between job demands and resources and associated outcome variables are indicated in Table 1. The relationships confirm the expected positive influence of job demands on well-being, and the negative influence of job demands on motivational processes. Consistent with the JD-R model, work engagement was the most studied dependent variable in the extracted studies (Alzyoud, 2016; Converso et al., 2019; Han et al., 2019; Mudrak et al., 2018; Nurendra, 2018). As expected, a negative relationship existed between job demands and work engagement, and a positive relationship between job resources and work engagement. The second most studied dependent variable was emotional exhaustion (as a proxy for burnout), with results indicating the positive effect of job resources on curbing burnout, and the amplifying effect of job demands on emotional exhaustion (Converso et al., 2019; Han et al., 2019). In all of the extracted studies, job resources improved positive outcomes such as work engagement and job satisfaction. Similarly, job demands negatively impacted work engagement and job satisfaction, whilst also enhancing the severity of emotional exhaustion, psychological distress, workaholism, work-family conflict and intentions to leave.

\section{Discussion}

The overarching aim of this systematic review was to identify the empirical, peer-reviewed, and published research on job demands and job resources of academic employees, underpinned by the JD-R model. This was done by identifying demands that impair work processes and resources that assist work processes. The review focused on studies conducted on all available published studies between 2014 and 2019 that met the criteria for inclusion. Specifically, the review endeavoured to identify the specific job demands and job resources experienced by academics in Higher Education institutions.

The results indicated social support from colleagues (Han et al., 2019; Mudrak et al., 2018) and social support (Alzyoud, 2016; Nurendra, 2018) as empirically verified job resources. This is in line with statements by Bakker, Demerouti and Euwema (2005) who indicated that the support from colleagues is instrumental in assisting academics to complete tasks on time, thereby reducing workload. The level of the academic's autonomy was also seen as a job resource. Job resources such as autonomy, social support, feedback on performance and personal development reflect a positive correlation with work attachment (Xanthopolou, Bakker, Demerouti \& Schaufeli, 2009). Therefore, increased levels of work attachment usually result in higher levels of work commitment and engagement. Thus, job resources could appear to be a solution for those whose jobs have moderately high demands, because employees could utilise the resources available to help them cope with copious demands. However, if job demands become too high, employees will engage less and this results in lower levels of commitment and intention to leave (Alzyoud, 2016).

Finally, from a personal resource perspective, teacher efficacy was shown to have an effect on academic employees' level of engagement (Han et al., 2019). Efficacy has been shown to be one of the dimensions for psychological capital. Psychological capital, in this regard, refers to an academic's level of confidence in being able to deal and succeed with challenging tasks. In this case, the more confident the individual, the higher the level of performance and engagement (Luthans, Youssef \& Avolio, 2007). 
In the present study, more quantitative job demands than qualitative job demands were found.

Job demands, quantitative demands, work-family conflicts and job insecurity were almost exclusively associated with stress (Mudrak et al., 2017). According to Lashuel (2020), it is often not realised soon enough by academics that poor work-life balance and pretending that one has everything under control, comes at a penalty to health, wellbeing and family relationships. Pressure, stress and anxiety often end up negatively affecting one's sleep patterns, increases exhaustion, frustration and loneliness, all of which impacts ones quality of life and relations with scholars and co-workers.

Job demands and job resources are quite specific to the academic environment. Thus, one can establish that the outcomes are consistent with those of earlier studies applying the JD-R model to numerous occupational contexts (Boyd, Grossman, Loeb \& Wyckoff, 2011) and therefore provide supporting evidence for the applicability of the JD-R model in the context of higher education. By reviewing the empirically validated job demands and resources, the researchers produced a list of the most salient job demands and resources experienced by members of academic staff. This can now be used to test the prevalence of these job demands and resources in HEIs, and inform interventions.

\section{Limitations and Recommendations}

Potential limitations of the study may include the small number of studies included. From the review it was evident that specific job demands and job resources were often grouped together for measurement, rather than specifying specific demands and resources. In addition, even though only high or moderate-quality reviews were reported, as a best-evidence synthesis, conclusions are dependent on the quality of the researchers' primary studies.

Future research should continue exploring and refining how different forms of job demands and resources, when promoted and stimulated, can produce positive outcomes for academic employees, specifically within local contexts. The results of this review indicated workload as the most prevalent job demand for academics. However, this may not be true in all countries or regions. Thus, the search for understanding the actual work situation of higher education academics is of paramount importance, given the relevance of what they are supposed to accomplish in society. Moreover, even though it is widely known that the future of a nation passes through the hands of good teachers, these experts have been undergoing moments of crisis and devaluation in their careers (Mercali \& Costa, 2019). One such example is the Covid-19 pandemic which deeply influenced work sectors, including academia. Academic employees were confronted with additional workload, work-life interference due to increased domestic and childcare responsibilities, as well as the need to engage in emergency remote learning (Bao, 2020). Thus, further research would need to consider this aspect to determine its impact of job demands and resources amongst academics.

By engaging academic staff in career discussions, involvement in large group meetings, job redesign, job-related training, employee enablement, career improvement, building relations with co-workers, and job crafting (Wärnich, Carrell, Elbert \& Hatfield, 2015; Rothmann, 2014), would likely improve an individual's job performance. An example of this would be job crafting training, which guides employees on how to proactively alter their own work environment and is a beneficial means for managing organisational stress and further work pressures (Wrzesniewski, 2012).

\section{Conclusion}

In conclusion, this systematic review has assisted in reinforcing the concept that job resources would promote and sustain employee engagement in today's organisations (Converso et al., 2019). There is consequently a need for Higher Education Institutions to focus on increasing resources for academics as it will mean having a sustainable workforce in addition to assisting their workforce in managing their demands. This can be done by using interventions that can actively teach academics how to manage their demands and to exploit their resources (Converso et al., 2019). By utilising the information put forward in this systematic review, academic institutions can tailor interventions to address specific job demands and resources. With this being said, this review sheds light and puts emphasis on the fact that there is still a need for further research to be carried out to determine the challenges and other drivers that exist within HEI's, especially in the South African context (Mouton, Louw \& Strijdom, 2013).

\section{References}

Alzyoud, A. A. Y. (2016). Job demands and Job resources on work engagement mediating by Job Satisfaction in Jordan Higher Education Sector. International Journal of Social Science and Economic Research, 1(5), 488-506. 
Arksey, H., \& O'Malley, L. (2005). Scoping studies: Towards a methodological Framework. International Journal of Social Research Methodology, 8(1), 19-32. https://doi.org/10.1080/1364557032000119616

Bao, W. (2020). COVID-19 and online teaching in higher education: A case study of Peking University. Hum Behav \& Emerg Tech. 2020, 1-3. https://doi.org/10.1002/hbe2.191

Bakker, A. B., \& Demerouti, E. (2018). Multiple levels in job demands-resources theory: Implications for employee well-being and performance. In E. Diener, S. Oishi, \& L. Tay (Eds.), Handbook of wellbeing. Salt Lake City, UT: DEF Publishers.

Bakker, A. B., \& Demerouti, E. (2007). The job demands-resources model: State of the art. Journal of Managerial Psychology, 22(3), 309-328. https://doi.org/10.1108/02683940710733115

Bakker, A. B., Demerouti, E., \& Euwema, M. C. (2005). Job resources buffer the impact of job demands on burnout. Journal of Occupational Health Psychology, 10, 170-180. https://doi.org/10.1037/1076-8998.10.2.170

Bakker, A. B., Demerouti, E., \& Verbeke, W. (2004). Using the Job Demands-Resources model to predict burnout and performance. Human Resource Management, 43(1), 83-104. https://doi.org/10.1002/hrm.20004

Bakker, A. B., Demerouti, E., Taris, T., Schaufeli, W. B., \& Schreurs, P. (2003). A multi-group analysis of the job demands - resources model in four home care organizations. International Journal of Stress Management, 10(1), 16-38. https://doi.org/10.1037/1072-5245.10.1.16

Barkhuizen, E. N. (2005). Work wellness of academic staff in higher education institutions. Unpublished Doctoral Thesis, Northwest University. http://hdl.handle.net/10394/713

Barrick, M. R., Mount, M. K., \& Li, N. (2013). The Theory of Purposeful Work Behavior: The Role of Personality, Higher-Order Goals, and Job Characteristics. The Academy of Management Review, 38(1), https://doi.org/10.5465/amr.10.0479

Bennett, S., \& Lockyer, L. (2004). Becoming an Online Teacher: Adapting to a Changed Environment for Teaching and Learning in Higher Education. Educational Media International, 41(3), 231-248. https://doi.org/10.1080/09523980410001680842

Bowin, R. B. (2001). Human resource management: An experiential approach (2nd ed.) Upper Saddle River, NJ: Prentice-Hall.

Bowling, N., \& Kirkendall, C. (2012). Workload: A review of causes, consequences and potential interventions. In J. Houdmont, S. Leka, \& R. Sinclair (Eds.), Contemporary occupational health psychology: Global perspectives on research and practice (Vol. 2, pp. 221-238). Chichester: John Wiley \& Sons. https://doi.org/10.1002/9781119942849.ch13

Boyd, D., Grossman, P., Loeb, S., \& Wyckoff, J. (2011). The Influence of School Administrators on Teacher Retention Decisions. American Educational Research Journal, 48(2), 303-333. https://doi.org/10.3102/0002831210380788

Byrne, O., \& MacDonagh. J. (2017). What's love got to do with it? Employee engagement amongst higher education workers. Irish Journal of Management, 36(3), 189-205. https://doi.org/10.1515/ijm-2017-0019

Chang, T. S., McKeachie, W., \& Lin, Y. G. (2010). Faculty Perceptions of Teaching Support and Teaching Efficacy in Taiwan. Higher Education, 59(2), 207-220. https://doi.org/10.1007/s10734-009-9243-8

Chen, S., Westman. M., \& Eden, D. (2009). Impact of Enhanced Resources on Anticipatory Stress and Adjustment to New Information Technology: A Field-Experimental Test of Conservation of Resources Theory. Journal of Occupational Health Psychology, 14(3), 219-230. https://doi.org/10.1037/a0015282

Converso, D., Sottimano, I., Molinengo, G., \& Loera, B. (2019). The Unbearable Lightness of the Academic Work: The Positive and Negative Sides of Heavy Work Investment in a Sample of Italian University Professors and Researchers. Sustainability, 11, 2439. https://doi.org/10.3390/su11082439

Council on Higher Education. (2010). Reflections of South African university leaders. Pretoria, South Africa: CHE. DOI:978-1-928331-09-4

Council on Higher Education. (2016). VitalStats: Public higher education 2014. Pretoria, South Africa: CHE. DOI:978-0-9946785-8-4

Deci, E. L., Eghrari, H., Patrick, B. C., \& Leone, D. R. (1994). Facilitating internalization: The self-determination theory perspective. Journal of Personality, 62(1), 119e142. https://doi.org/10.1111/j.1467-6494.1994.tb00797.x 
Demerouti, E., \& Bakker, A. B. (2011). The Job Demands-Resources model: Challenges for future research. Journal of Industrial Psychology/SA Tydskrif vir Bedryfsielkunde, 37(2), Art. \#974, 9 pages. https://doi.org/10.4102/sajip.v37i2.974

Demerouti, E., A. B. Bakker, F. Nachreiner, \& W. B. Schaufeli. (2001). "The Job Demands-Resources Model of Burnout.” Journal of Applied Psychology, 86(3), 499-512. https://doi.org/10.1037/0021-9010.86.3.499

Dhanpat, N., de Braine, R., \& Geldenhuys, M. (2019). Preliminary development of the Higher Education Hindrance Demands Scale amongst academics in the South African context. SA Journal of Industrial Psychology, 45, 1595. https://doi.org/10.4102/sajip.v45i0.1595

Du Plessis, M. (2020). Model of coping with occupational stress of academics in a South African higher education institution. SA Journal of Industrial Psychology/SA Tydskrif vir Bedryfsielkunde, 46(0), a1714. https://doi.org/10.4102/sajip.v46i0.1714

Du Plessis, M., \& Martins, N. (2019). Developing a measurement instrument for coping with occupational stress in academia. SA Journal of Industrial Psychology/SA Tydskrif vir Bedryfsielkunde, 45(0), a1653. https://doi.org/10.4102/sajip.v45i0.1653

Dvorackova, J., Pabian, P., Smith, S., Stockelova', T., Sima, K., \& Virtova', T. (2014). Politika a každodennost na česky'ch vysoky'ch s`kola'ch. Praha: Sociologicke' nakladatelstvi' SLON.

Edmondson, A. C., Higgins, M., Singer, S., \& Weiner, J. (2016). Understanding Psychological Safety in Health Care and Education Organizations: A Comparative Perspective. Research in Human Development, 13(1), 65-83. https://doi.org/10.1080/15427609.2016.1141280

Edmondson, A. C., \& Lei, Z. (2014). Psychological safety: The history, renaissance, and future of an interpersonal construct. Annual Review of Organizational Psychology and Organizational Behavior, 1(1), 23-43. https://doi.org/10.1146/annurev-orgpsych-031413-091305

Gillespie, N. A., Walsh, M., Winefield, A. H., Dua, J., \& Stough, C. (2001). Occupational stress in universities: Staff perceptions of the causes, consequences and moderators of stress. Work \& Stress, 15, 53-72. https://doi.org/10.1080/02678370117944

Gabel-Shemueli, R., Dolan S. L., \& Ceretti, S. Being engaged: The multiple interactions between job demands and job resources and its impact on nurses engagement. International Journal of Nursing, 3(2), 17-32. Retrieved from https://www.ijnonline.com/index.php/ijn/article/view/155

Han, J., Yin, H., Wang, J., \& Bai, Y. (2019). Challenge job demands and job resources to university teacher well-being: the mediation of teacher efficacy. Studies in Higher Education. https://doi.org/10.1080/03075079.2019.1594180

Hakanen, J. J., Peeters, M. C. W., \& Perhoniemi, R. (2011). Enrichment processes and gain spirals at work and at home: A 3-year cross-lagged panel study. Journal of Occupational and Organizational Psychology, 84(1), 8-30. https://doi.org/10.1111/j.2044-8325.2010.02014.x

Heleta, S. (2016). Decolonisation of higher education: Dismantling epistemic violence and Eurocentrism in South Africa. Transformation in Higher Education, 1(1), 1-8. https://doi.org/10.4102/the.v1i1.9

Higher education global trends and emerging opportunities to 2020, retrieved 08, 19, 2020, University of the Free State. htttps://www.ufs.ac.za.

Hobfoll, S. E. (2002). Social and psychological resources and adaptation. Review of General Psychology, 6, 307- 324. https://doi.org/10.1037/1089-2680.6.4.307

Hoy, A. W. (2004). "Self-Efficacy in College Teaching." Essays on Teaching Excellence. Toward the Best in the Academy, 15(7), $\quad 8-11 . \quad$ Retrieved from http://www.podnetwork.org/publications/teachingexcellence/03-04/V15,\%20N8\%20WoolfolkHoy.pdf

Isaacs, S. A., Roman, N. V., Savahl, S., \& Sui, X. C. (2018). Using the RE-AIM framework to identify and describe best practice models in family-based intervention development: A systematic review. Child \& Family Social Work, 23(1), 122-136. https://doi.org/10.1111/cfs.12380

Janse van Rensburg, C Rothmann, S., \& Diedericks, E. (2018). Job demands and resources: Flourishing and job performance in South African universities of technology settings. Journal of Psychology in Africa, 28(4), 291-297. https://doi.org/10.1080/14330237.2018.1501881 
Kinman, G., Jones, F., \& Kinman, R. (2006). The well-being of the UK academy, 1998-2004. Quality in Higher Education, 12(1), 15-27. https://doi.org/10.1080/13538320600685081

Kumar, S., Duggirala, M., Hayatnagarkar, H. G., \& Balaraman, V. (2017). Understanding impact of supervisory support on work outcomes using agent based simulation. DIAS/EDUDM@ISEC. DOI: 10.1145/nnnnnnn.nnnnnnn

Lashuel, H. A., (2002). Mental Health in Academia. What about Faculty? eLife, (9), 54551. https://doi.org/10.7554/eLife.54551

Luthans, F., Youssef, C. M., \& Avolio, B. J. (2007). Psychological capital: Developing the human competitive edge, Oxford: Oxford University Press. ISBN-13 978-0-19-518752-6

Mazzetti, G., Guglielmi, D., \& Topa, G. (2020). Hard Enough to Manage My Emotions: How Hardiness Moderates the Relationship Between Emotional Demands and Exhaustion. Frontiers Psychology, 11, 1194. https://doi.org/10.3389/fpsyg.2020.01194

Mercali, G. D., \& Costa, S.G. (2019). Antecedants of work engagement of Higher Education Professors in Brazil. Human and Social Management, 20(1), 1678-6971. https://doi.org/10.1590/1678-6971/eramg190081

Moher, D., Liberati, A., Tetzlaff, J., Altman, D. G., \& The PRISMA Group. (2009). Preferred reporting items for systematic reviews and meta-analyses: the PRISMA statement. PLoS Med, 6(7), e1000097. https://doi.org/10.1371/journal.pmed.1000097

Moloney, W., Peter Boxall, P., Parsons, M., \& Cheung, G. (2017). Factors predicting Registered Nurses'intentions to leave their organization and profession: A job demands-resources framework. Journal of Adv Nursing, 74, 864-875. https://doi.org/10.1111/jan.13497

Mouton, N., Louw, P., \& Strydom, G. L. (2013). Present-Day Dilemmas and Challenges of the South African Tertiary System. International Business \& Economics Research Journal, 12(3), 285-300. https://doi.org/10.19030/iber.v12i3.7672

Mostert, K. (2011). "Job characteristics, work-home interference and burnout: testing a structural model in the South African context". International Journal of Human Resource Management, 22(5), 1036-1053. https://doi.org/10.1080/09585192.2011.556777

Mudrak, J., Zabrodska, K., Kveton, P., Jelinek, M., Blatny, M., Solcova, I., \& Machovcova, K. (2018). Occupational Well-being Among University Faculty: A Job Demands-Resources Model. Research of Higher Education, 59, 325-348. https://doi.org/10.1007/s11162-017-9467-x

Mushemeza, E. D. (2016). Opportunities and Challenges of Academic Staff in Higher Education in Africa. International Journal of Higher Education, 5(3), 236-246. https://doi.org/10.5430/ijhe.v5n3p236

Ngoc, H. D., Hoang, L. H., \& Hung, V. X. (2020). Transforming Education with Emerging Technologies in Higher Education: A Systematic Literature Review. International Journal of Higher Education, 9(5), 252. https://doi.org/10.5430/ijhe.v9n5p252

Nurendra, A. M. (2018). The effect of Job demands as a moderating variable between Job demands and work engagement on University Lecturers. Malaysian online journal of counselling, 5(1), 35-42. http://mojc.um.edu.my/

Ntshoe, I., \& De Villiers, P. (2008). Steering the South African higher education sector towards transformation. Perspectives in Education, 26(4), 17-27. https://hdl.handle.net/10520/EJC87500

Pienaar. C., \& Bester, C. (2009). Addressing career obstacles within a changing higher education environment: Perspectives of academics South African Journal of Psychology. Suid-Afrikaanse Tydskrif vir Sielkunde, 39(3), 376-385. https://doi.org/10.1177/008124630903900311

Pillay, S. (2015). Decolonising the university, Africa is a Country. Retrieved 07, 01, 2020, from, http:// africasacountry.com/2015/06/decolonizing-the-university/.

Prudky, L., Pabian, P., \& Sima, K. (2010). Ceske' vysoke' s`kolstvı'. Na ceste ${ }^{`}$ od elitnı'ho k univerza'lnı'muvzde`la'va'nı' 1989-2009. Praha: Grada.

Renshaw, T. L., Long. A. C., \& Cook. C. R. (2015). Assessing Adolescents' Positive Psychological Functioning at School: Development and Validation of the Student Subjective Wellbeing Questionnaire. School Psychology Quarterly, 30(4), 534-552. https://doi.org/10.1037/spq0000088 
Roe, R. A., \& Zijlstra, F. R. H. (2000). Work pressure. Results of a conceptual and empirical analysis. In M. Vartiainen, F. Avallone \& N. Anderson (Eds.), Innovative theories, tools, and practices in work and organizational psychology (pp. 29-45). Ashlans, OH: Hogrefe \& Huber Publishers.

Roman, N. V., \& Frantz, J. M. (2013). The prevalence of intimate partner violence in the family: A systematic review of the implications for adolescents in Africa. Family Practice, 30, 256-265. https://doi.org/10.1093/fampra/cms084

Rothmann, S. (2014). Flourishing in work and careers In M Coetzee (Ed), Psycho-social career meta-capacities: Dynamics of contemporary career development ( $\mathrm{pp}$ 203-220) Dordrecht, The Netherlands: Springer. https://doi.org/10.1007/978-3-319-00645-1_11

Rothmann, S., \& Essenko, N. (2007). Job characteristics, optimism, burnout, and ill health of support staff in a higher education institution in South Africa. South African Journal of Psychology, 37(1), 135-152. https://doi.org/10.1177/008124630703700110

Saks, A. M. (2006). Antecedents and consequences of employee engagement. Journal of Managerial Psychology, 21, 600-619. https://doi.org/10.1108/02683940610690169

Schaufeli, W. B. (2017). Applying the Job Demands-Resources model: A 'how to' guide to measuring and tackling work engagement and burnout. Organizational Dynamics, 46(2), 120-132. https://doi.org/10.1016/j.orgdyn.2017.04.008

Schaufeli, W., Salanova, M., González-Romá, V., \& Bakker, A. B. (2002). The measurement of engagement and burnout: A two sample confirmatory factor analytic approach. Journal of Happiness Studies, 3, 71-92. https://doi.org/10.1023/A:1015630930326

Schaufeli, W. B., \& Taris, T. W. (2014). A Critical Review of the Job Demands-Resources Model: Implications for Improving Work and Health in G.F. Bauer and O. Hämmig, Bridging Occupational, Organizational and Public Health: A Transdisciplinary Approach. https://doi.org/10.1007/978-94-007-5640-3_4

Shirom, A., Nirel, N., \& Vinokur, A.D. (2006). Overload, autonomy, and burnout as predictors of physicians quality of care. Journal of Occupational Psychology, 11(4), 382-342. https://doi.org/10.1037/1076-8998.11.4.328

Torp, S., Lysfjord, L., \& Midje, H. H. (2018). Workaholism and work-family conflict among university academics. Higher Education, 76, 1071-1090. https://doi.org/10.1007/s10734-018-0247-0

van Veldhoven, M. (2014). Quantitative job demands. In M. C. W. Peeters, J. De Jonge, \& T. W. Taris (Eds.), An introduction to contemporary work psychology (pp. 117-143). Wiley Blackwell.

Viljoen, J. P., \& Rothmann, S. (2002). Transformation in a tertiary education institution: A case study. Management Dynamics, 11(2), 2-9. https://hdl.handle.net/10520/EJC69645

Wärnich, S., Carrell, M. R., Elbert, N. F., \& Hatfield, R. D. (2015). Human resource management in South Africa ( $5^{\text {th }}$ ed.). Hampshire, United Kingdom: Cengage Learning.

Wrzesniewski, A. (2012). Callings In K. S Cameron \& G. M Spreitzer (Eds.), The Oxford handbook of positive organizational scholarship ( $p$ p 45-55). New York, NY: Oxford University Press.

Xanthopolou, D., Bakker, A., Demerouti, E., \& Schaufeli, W. (2009). Reciprocal Relationship between Job Resources, Personal resources and Work engagement. Journal of Vocational Behavior, 74, 235-244. https://doi.org/10.1016/j.jvb.2008.11.003

\section{Copyrights}

Copyright for this article is retained by the author(s), with first publication rights granted to the journal.

This is an open-access article distributed under the terms and conditions of the Creative Commons Attribution license (http://creativecommons.org/licenses/by/4.0/). 